\title{
Determining Factors in the Development of Religious Tourism Destination Marketing Strategy (A Case Study in Greater Malang)
}

\author{
Kukuh Lukiyanto*, Etsa Astridya Setiyati, Choirul Huda and Albert Verasius \\ Dian Sano
}

\author{
Entrepreneurship Department, Undergraduate Program, BBS, Binus Unversity Malang Campus, Jl. Araya \\ Mansion No. 8 - 22, Araya, Malang, Jawa Timur-Indonesia \\ ${ }^{*}$ Corresponding author email: kukuh.lukiyanto@binus.ac.id
}

\begin{abstract}
Religious tourism in Indonesia is growing rapidly, along with the improvement of the community's economy. Culture and the community's beliefs are among the factors affecting it. Greater Malang has many potential and developable religious tourism destinations. Learning from the two well-known religious tourism destinations, we aim to uncover factors that make tourists loyal to these two religious tourism destinations. These factors are used for mapping and formulating marketing strategy. This research is essential and a novelty as there has not been any research discussing the same theme. These two wellknown religious tourism destinations do not have a marketing strategy in their management. They are simply run as they are and have not been professionally managed. With the qualitative method, the study results show that culture-based faith groups as a target market for religious tourism, the mystical and unique story as positioning, and showing routine attractions to build interest are the three main keys that attract tourists to come to religious tourism destinations repeatedly. The results of this study can be used as a reference to develop marketing strategies for existing religious tourism destinations and improve the potential of religious tourism in Greater Malang. Further research is essential to see whether this research's results apply to different areas or countries with the same community characteristics.
\end{abstract}

Keywords: religious tourism, tourist destinations, rituals, repeat visits, marketing strategies

\section{INTRODUCTION}

Greater Malang (Malang Raya) tourism potential is a developable sector asit can be a source of revenue for the government and community. Various types of tourism objects in Malang are potentials that can evolve into the tourism industry, among which are nature tourism as well as cultural, educational, religious, and special interest tourism(1,2). If amalgamated in developing tourism potential, the three governmental regions in Greater Malang: Malang City, Batu City, and Malang Regency, will become a significant economic force (1) Central Bureau of Statistics data reveals an increase in the number of tourists each year; itreaches 16.7 million in 2018 (Table 1).

TABLE 1. Number of Visitors in Greater Malang (2018)

\begin{tabular}{|c|c|c|c|}
\hline & Domestic & International & Total \\
\hline Malang Regency & $7,072,124$ & 100,234 & $7,172,358$ \\
\hline Malang Municipality & $3,795,229$ & 124,267 & $3,919,496$ \\
\hline Batu Municipality & $5,633,611$ & 10,557 & $5,644,168$ \\
\hline Total & $\mathbf{1 6 , 5 0 0 , 9 6 4}$ & $\mathbf{2 3 5 , 0 5 8}$ & $\mathbf{1 6 , 7 3 6 , 0 2 2}$ \\
\hline Percentage & $98.6 \%$ & $1.4 \%$ & $100 \%$ \\
\hline \multicolumn{2}{|r|}{ Source: Central Bureau of Statistics (2019) } \\
\hline
\end{tabular}

Lately, religious tourism, also called a pilgrimage, is a growing tourism potential. It is tourism that has existed for a long time and is motivated by memory, along with religious reasons $(3,4)$. Religious tourism is part of cultural tourism, which has triggered changes in tourist behavior. Ultimately, through religious tourism, religion can be a booming economic growth $(3,4)$. This opportunity is momentous, especially when a destination has various well-maintained holy sites 
and monuments. Consequently, Greater Malang is thought to be an ideal destination for the development of religious tourism because of its multi-cultural history $(1,5)$.

Greater Malang, as a multi-cultural area and with diverse beliefs in the past, left their historical traces. Historical relics in the form of culture, traditional villages, pesarean, temples, mosques, temple churches, and many others, convert to a potential ready to be developed. In general, local people are familiar with these tourist objects; on a national or international scale; however, the sites need to be further developed. The existing potential, such as religious tourism, is developable into a destination that can attract many visitors.

Greater Malang has two tourism destinations capable of attracting both local and international visitors. First, the Tiban Mosque in the southern region, which is a Muslim-based place for worship with unique architecture (6). Besides its impressive architecture, this mosque has a unique story as people believe that the construction process was completed in one night because it was assisted by 'Jinn,' an invisible creature in the universe $(6,7)$. The mosque is called "tiban" (a Javanese word, which means 'all of a sudden') because it appeared instantaneously. Many local and foreign tourists visit this mosque, especially those from the Asian region.

The second destination is famous religious tourism called Gunung Kawi Temple and Pesarean, located on the slopes of Mount Kawi in the south western region of Greater Malang. It is a Confucian temple next to a mosque. This place is the former hermitage of RM Imam Soedjono (a residence and school that spread Islam in the area) and pesarean (tomb) EyangJugo, teacher of RM Imam Soedjono (8,9). For some Muslim communities, the tomb of religious leaders is a sacred place that can bring them blessings if they do alms or worship there $(6,7)$. It is said that R.M Imam Soedjono welcome da wanderer from China. After receiving advice and prayers from R.M Imam Soedjono, the wanderer succeeded in his business when returning to China. To date, this place is believed to bring blessings to those praying for wealth/success (10). Many local tourists and foreigners from Asia, Australia, and Europe, especially those of Chinese descent, visit this place. People who believe that their success came from praying in this place develop the area and temple.

Both of these tourist destinations have not been professionally managed, but the number of tourist visits increases every year. According to the manager, in 2018, around 160,000 tourists were visiting Gunung Kawi, and more than 2 million visitors were visiting the Tiban Mosque in the same year. It is an intriguing phenomenon; these two destinations are not massive places, they do not have extraordinary attractions or adequate facilities, but certain people know them very well. The number of visits continues to increase each year, and more tourists visit in special sessions. The places are limitedly promoted; instead, they are known through word-of-mouth publicity. Those who have come to this place tell others about their satisfaction (11). What makes this research different from previous studies on tourist destinations is, in general, previous studies stated that customer satisfaction arises from interesting objects, the availability of facilities, services and (11-16).

This study examines the effective marketing strategies of religious tourism destinations from the success of previously mentioned religious tourism destinations. We identify the factors affecting the success of marketing the two tourist destinations, which are the objects of this research. There has not been a study discussing the topic that focuses on the tourists' perspective when visiting the place and being satisfied when they do religious activities there. We examine further factors that can encourage tourists to visit this place.

The study results can later be used to develop marketing strategies to improve the potential of other religious tourism in Malang. It also can be used to enhance the implementation in both tourist destinations used as the objects of this research. On a more substantial benefit, the results of this study can also be used to develop marketing strategies for tourist destinations with similar characteristics and similar cultural background of the community.

\section{RELIGIOUS TOURISM}

Religious tourism appears simultaneously with the history of human existence. Previous research shows that religious tourism for a particular religion has been started since ancient times (3). Based on the term homo religion, humans have long been related to religion. It began when humans wanted to overcome their fear when observing the sky and felt safe with the help of superior beings. The human need to understand between real and supernatural conditions, especially to understand the nature around them that makes no sense eventually gave rise to religion 
(3). Over the centuries, religious beliefs have undergone many changes, but religious practices are still practiced in the same way and followed by their followers. In the teachings of the Muslim religion, for instance, a visit to the Holy Land is an obligation; in the past, people had difficulties in transportation, food, water and the road to the Holy Land was very dangerous, but this did not weaken their will (17).

All of the information above reveals the meaning and motivation of religious tourism. It is a unique form of historical and cultural tourism. However, people argue that religious tourism covers knowledge of religion, heritage, and customs as a form of culture (3). Through 'religious' travel, tourists have the opportunity to study architecture and religious art and strengthen their faith in God. The experience of religious tourism makes tourists explore more and take part in religious events and be active in a religious environment (18). Tourists through their religious travels and positive interactions with others will share their religious tourism experiences.

Still difficult to describe the characteristics of religious tourists due to the limitations of the literature. From several studies, in the Asian region, religious tourists are identified as tourists with strong cultural attachments and beliefs in fanatic religions. Both cannot be separated due to cultural and religious assimilation (4,19-21).

\section{SUSTAINABILITY OF TOURISM CULTURE AND RELIGION}

Cultural heritage, such as temples, monuments, or heritage trails in ancient times, has been actively explored and converted to tourist destinations in many countries. Cultural heritage is a legacy in the form of combined of something tangible and intangible from human life in the past (22). Governments in many countries develop the potential of historical heritage to protect, develop, and advance national culture, as well as to convertit to attractive tourist destinations. Supporting facilities are built to attract tourists.

Religious tourism is currently trending along with the improvement of the world's economy. This type of tourism is said to significantly influence local communities in three components: economic, community, and environment. The local communities are the core elements that bring a balance between the economy, society, and the environment for cultural and tourism sustainability $(1,5)$. Relics of the past, of which within and the surrounding area have been developed and expanded, like monuments, temples, tombs, or other forms, will benefit the nearby community and bring economic impacts; employment opportunities are created, and ancient traditions will not perish.

Modern society understands cultural values as a legacy and that they must be preserved. A cultural heritage that is damaged due to old age, social distortion, and environmental pollution, must be repaired for its preservation. Maintaining the diversity of cultural heritage is an effort to preserve and create sustainable tourism. In tourism theory, sustainable tourism depends on economic, social, and environmental balance; the balance can be achieved by preserving cultural heritage $(23,24)$, which requires high cost. It is undoubtedly challenging to achieve without involving the local community (23). The community will not want to be actively involved in preserving cultural heritage if there are no economic factors as the driving force $(1,25-27)$. The sustainability of cultural or religious-based tourism drives the community's economy and conserve the cultural heritage itself.

\section{METHODOLOGY}

This study is descriptive qualitative research. The data were collected in Greater Malang from two religious tourism destinations: Pesarean Gunung Kawi and Tiban Mosque. Information was collected through parallel studies with in-depth interviews, literature reviews, and observations. The purposive sampling method was used to determine the informants (28). The informants' main criteria were those having visited one of the two tourist destinations for at least twice. Informants were determined based on age group, education, number of visits, and level of satisfaction with the tourist destinations to achieve uniformity. The age group was between 30-60 years old; based on the manager's information, most of the visitors were of this age group. On education criteria, those who graduated from high school and university were selected because they were expected to explain the information readily as needed by the researchers. The informants were local tourists only, domiciled in several regions of Indonesia; 11 informants took part in this research. This number was determined based on the uniformity of the answers given; if the answers given are already saturated or similar to those of the previous informants, the number is considered sufficient, and there is no need to add more informants $(28,29)$. 
TABLE 2. Informants' Description

\begin{tabular}{|c|c|c|c|c|c|}
\hline No. & $\begin{array}{l}\text { Informant } \\
\text { Code }\end{array}$ & Age & Education & $\begin{array}{l}\text { Satisfaction Rate (qs/quite } \\
\text { satisfied - s/satisfied - vs/sery } \\
\text { satisfied) }\end{array}$ & $\begin{array}{c}\text { Number of } \\
\text { Visits }\end{array}$ \\
\hline 1 & AA & 35 & SHS & vs & 2 \\
\hline 2 & DI & 40 & Univ. & vs & 4 \\
\hline 3 & SD & 45 & Univ. & vs & 3 \\
\hline 4 & JA & 32 & Univ. & $\mathrm{s}$ & 2 \\
\hline 5 & SU & 46 & SHS & vs & Every year \\
\hline 6 & SS & 56 & Univ. & $\mathrm{s}$ & 3 \\
\hline 7 & $\mathrm{ME}$ & 53 & SHS & vs & Every year \\
\hline 8 & $\mathrm{M}$ & 55 & SHS & vs & 5 \\
\hline 9 & KL & 58 & SHS & vs & 4 \\
\hline 10 & MF & 35 & Univ. & $\mathrm{s}$ & 2 \\
\hline 11 & EA & 44 & Univ. & qs & 2 \\
\hline
\end{tabular}

Literature research is based on studies conducted by previous researchers, journals, and other articles related to the two tourist destinations. The journal or article publishes studies examining tourist profiles, the purpose of visits, and the satisfaction of tourists visiting both destinations. Field observations aimed to see the management of physical and other components to attract and provide satisfaction for tourists. Literature studies and observations were conducted as a process of validating data from indepth interviews. In qualitative research, the data obtained's truth needs to be validated by triangulation to ensure the validity of the data collected and processed (30).

After collecting information, conducting field observation, and validation, the next step is data processing $(30,31)$ to formulate target markets and position tourist destinations. All information and findings will be used to plan and establish marketing strategies for new religious tourism destinations to be developed.

\section{OVERVIEW OF THE RESEARCH OBJECT}

\subsection{Gunung Kawi Temple and Pesarean}

According to Soeryowidagdo (1989), in his book entitled Pesarean Gunung Kawi, the development of Gunung Kawi religious tourism began with the history of RM Imam Soedjono hermitage establishment, a pupil of Eyang Jugo (the Prince of Mataram who escaped from the pursuit of the Dutch invaders and ordered his pupil to bury his body in Padepokan RM Imam Soedjono when passing away). In this area, RM Imam Soedjono spread Islam to residents who were still Hindu and Buddhist. RM Imam Soedjono's supernatural and healing ability developed the hermitage rapidly. The place became widely famous. It is said that R.M Imam Soedjono welcomed a wanderer from China. After receiving advice and prayers from R.M Imam Soedjono, the wanderer succeeded in his business when returning to China. To date, this place is believed to bring blessings for those praying for wealth/success $(9,10)$. Local people know that many Indonesian conglomerates are doing rituals and alms at this place. They also helped develop the Pesarean. For Muslim visitors, it is a tourist destination in the form of a holy place. Some Muslim groups believe that the tomb of a great person or exalted leader is sacred and can give blessings to people doing pilgrimage (religious tourism) or praying there (10).

\subsection{Tiban Mosque}

The Tiban Mosque is located in a 2-hectares area of a Pesantren (a boarding school for students studying Islam) named Salafiyah Bihaaru Bahri 'Asali Fadlaailir Rahmah. The Tiban Mosque has a unique architecture that blends ornaments typical of Turkey, India, Russia, and Egypt combined into one beautiful place of worship (Febrianto et al., 2018). According to the management, the 10-story mosque was built without architectural planning but based on results of istikhoroh (seeking God's guidance through prayers and the answer is usually felt within the heart, based on the Quran and Al-Sunnah). The process began in 1978 by the santri (pesantren students). Besides its unique architecture, this mosque has an interesting story stating that the construction process was completed in one night because a 'Jinn' assisted it; it is a creature in the universe that is invisible to human eyes $(7,32)$. The 
mosque is called "Tiban" (a Javanese word, which means 'all of a sudden') because it instantly appeared.

According to the mosque's manager, the story above is the main attraction for tourists, but the fact is not the case. The development process is carried out as is generally done by santri while closing the construction area. The surrounding community does not know if there is a building construction process. After seeing several floors of the building constructed, people assume the mosque appeared suddenly. This sudden appearance is associated with people's belief in other creatures in the universe that can help humans. This story attracts local and foreign tourists, especially those from the Asian region, to prove the truth. They are not limited to the Muslim community but from various tribes, races, and beliefs. Data from the mosque's manager shows that around two thousand people visit on ordinary days, approximately 10 thousand people visit on holidays, and 14 thousand people visit in the Lebaran season (Muslims' holiday).

\section{DISCUSSION}

\subsection{Objective}

The enthusiasm of tourists to visit religious tourism destinations in Greater Malang is very high these days. If managed or packaged into multi-religious products, potential tourist destinations in Greater Malang will attract tourists. Existing historical and cultural heritage can be a multi-religious religious tourism destination by highlighting certain elements. This destination will attract people with certain beliefs but will attract all tourists who want to know about the life and cultural diversity of the past. They are interested in visiting a tourist destination to enjoy the beauty of its architecture without having to worship at the place. They also visit because of cultural attractions shown on special occasions. A person who is not Muslim can visit the mosque, a Confucius if he wants to see temples, or a Christian to visit an ancient church. It only takes the love and interest of tourists about knowledge and culture to become a religious tourist $(3,22)$.

The results of data processing from in-depth interviews, literature studies, and grouping tourists of religious tourism destinations are as follow:

- Tourists who are interested in cultural and religious history

Speaking of religious tourism, we must remember that it is part of cultural tourism. The community still believes and upholds the local culture of their ancestors, regardless of their religion. The initial process of spreading religion, especially Islam in Java, was carried out through assimilation with the existing culture of the community. As a result, most Muslim communities still maintain local culture as part of the Muslim culture. They profess their encouragement to know more about culture in the past. It brought them to religious tourism destinations. However, due to a large number of religious tourism destinations, they make choices based on the uniqueness of the place. People find this uniqueness through media information or word of mouth. Interestingly, none of the informants find the place's uniqueness from tourism promotion or a travel agent.

When asked about the uniqueness triggering their interest, all informants gave the same answer: the mystical uniqueness of the destination. Although this does not make any sense, they can accept it because it is what the ancestors told. People's words are spreading that Tiban Mosque was built in only one night with the help of 'Jinn', and GunungKawi is a place where people can seek for 'pesugihan' (a way to obtain wealth instantly through making agreements with spiritual beings) trigger tourists to visit these places. Following their explanation:

JA (interviewed at the Tiban Mosque):

"I've visited both of them. I wanted to come because I was interested in people's stories, I wanted to see what the Tiban Mosque which is said to have been built by a 'Jinn' in one night. I was curious about Gunung Kawi because of the story telling that people seek for pesugihan and succeed. Actually, I don't believe (the stories), I just want to watch and travel while seeking knowledge. The building is unique, historic, and interesting, so when I pray there, it feels more solemn... The inner atmosphere is also different. So, I want to come here again."

$M F$ (interviewed at GunungKawi):

"We've also been to Tiban Mosque, just to travel, we don't believe in those mystical stories. I guess it is okay to find the fact, so we can travel and learn things from the place. We can learn much knowledge after coming to this place, the building is unique and interesting. A tourist destination like this need to be preserved so that our children and grandchildren can learn about the culture of this nation's ancestor." 
Tourists of this type are more motivated by the desire to travel, learn, and introduce cultural ancestors to their grandchildren. The data reveals that these tourists are university graduates and young people, meaning that this group puts forward rational but still respect the culture. They visit not because of the place's attraction but their self-encouragement. When viewed from the level of satisfaction, they are satisfied, willing to recommend to others, and revisit the place.

\section{- Pilgrims}

Tourists in this group are called the "Pilgrims." They are not interested in learning, but they only want to connect with God and ask for something through prayer. Praying at certain places that are considered sacred/special has a higher success rate regardless of the beliefs, and 8 out of 11 informants believe in this view. Gunung Kawi is perceived as a special place to pray for success and wealth. When praying, they bring uborampe (an item for rituals) or offerings for their prayers. Tourists used to bring the uborampe from home. This habit is seen as an opportunity by the local people to provide (sell) the uborampe packages for tourists. It makes it easy for the tourists, as explained by one of the informants:

"I often go there (Gunung Kawi) with friends. Well, I pray for running my business smoothly, ask for protection from our opponents ... business is hard, if we are not protected, we will be destroyed..it is now easy anyway, the locals have provided all uborampe (offerings for rituals). I used to have to bring it from home; sometimes, I was ashamed when seen by my neighbors, so I did it secretly".

Most of the pilgrims were those less educated, and they were entirely satisfied with the religious tourism destination. Because of the satisfaction, they visit the place frequently; some of them even visit this tourist destination every year. Their satisfaction is further triggered by inner satisfaction with the results of their prayers, not because of the tourist destination. The following are excerpts from ME (an interviewee) when asked about the frequency of arrivals and factors affecting satisfaction with tourist destinations:
"I go there every year to pray ... it is necessary to recharge our batteries ... he he he ... I'm pleased because all I need are now available here; we just come to the place, buy the equipment, and pray. I'm pleased not because the place is beautiful, nice, or something else, but because our purpose for coming to pray is now easy. Facilities like well-built roads, hotels, restaurants make it easier for us, although, without those things, we would still come here anyway."

The tourists' visit leads to an increased number of visitors at certain times, such as at the fasting month and Eid in the Tiban Mosque. To attract more tourists, managers make special events "Khataman" (reciting the Quran from beginning to end). The same thing happened at the Gunung Kawi complex mosque on the first day of the month of Suro (a month in the Javanese calendar). The manager held a selametan (a ritual of praying together to ask for blessings of safety, protection, and success). It is a form of their belief in culture; they come to a religious tourism spot at certain religious moments to get special blessings from God through a place considered sacred $(8,10,33)$. Thus, it can be understood that religious tourism, as part of the culture, can attract a large group of people.

\section{CONCLUSION}

\subsection{Culture-based faith groups as a target market for religious tourism}

Based on market segmentation for the development of religious tourism, various marketing models must be applied. Faith is the target base of developing religious tourism destinations; religious tourism is inseparable from the tourist mindset. The grouping of tourism based on faith is due to different perceptions among faith groups and will influence people act in a prescribed way; different so, understanding call for different approaches. Religious tourism products must be entirely different for each of the faith groups. Christians have different so, understanding from Muslims and Chinese descents, so their promotion must have a different character. Not all belief groups are the targets; thus, we focus more on those who still uphold ancestral culture. It is influenced by the model of the religion spread in Indonesia, which adopts local culture in the introduction process. Eventually, certain faith groups emerge, those who uphold the ancestral 
culture. This group still exists and dominates the trust model in Indonesia.

The results of the interviews showed that all informants visited religious tourism destinations were driven by the closeness to the culture adopted. It is in line with the research results by Sterchele (2020), that religious tourists are greatly influenced by their culture. These tourists will be willing to spend their money on tours to holy sites, including religious tourism destinations in Greater Malang (1,5).

The product's weaknesses can be transformed into benefits when searching for various aspects of the development of religious tourism in the great Malang. This procedure is crucial because it can improve tourism products. In the case of religious tourism, culture and knowledge prevail over religious service. It is undeniable that Greater Malang clearly shows its cultural tourism content. Therefore, it has the power to attract not only religious tourists and pilgrims, but also those who love the culture, history, and art. In conclusion, people targeted for developing religious tourism destinations are culture-based faith groups. The following is detailed marketing advice for the development of religious tourism in Greater Malang:

\subsection{The mystical and unique story as positioning for religious tourism destinations}

A community's belief in mystical matters as cultural heritage is still inherent and dominates Indonesian society. Although they have embraced certain religions, their cultural belief is still there (35). The spread of religion in Indonesia, which uses the cultural assimilation model, keeps the community adhering to the culture of ancestors (33). It is the factor that triggers all informants to come to religious tourism sites. Unique mystical stories encourage informants to prove the truth by visiting these tourist destinations. Indirectly, this will be a separate brand for tourist destinations. If the manager can seize this opportunity and adapt the stories into buildings and the surrounding environment, visitors will be satisfied. If the place development does not match people's stories, tourists will be disappointed and will not revisit the place as a long-term effect of disappointment.

For new tourist destinations, managers need to explore the history of the place and find interesting and mystical stories as a brand built for tourist destinations. They can focus more if the site is associated with certain beliefs. Since most of Indonesia's population are Muslims, it will develop better if it is related to their faith. However, if the site's history also indicates other faiths, the managers can add them to the concept. The mystical story of Tiban Mosque and Gunung Kawi as a place to pray for success and wealth is an example of the success of building a unique story as the positioning of a religious tourism destination.

\subsection{Showing routine attractions to build interest in visiting}

Cultural attractions are associated with the history and mystical stories built to make tourist revisit the site. The desire to immerse with the atmosphere and experience spirituality encourages visitors to come back. Some informants asserted that even though they have not gotten what they were seeking, they are willing to revisit, hoping to get what they want in the next visit. New religious tourism destinations need to explore the history and build religious attractions. Scheduling a certain period as an exclusive but regular event is done to attract the tourists. This schedule makes it easy for tourists to plan their visit.

The event of Khataman at Tiban Mosque in the fasting month and Eid is an example of a tourist attraction. Fasting Month as a holy month for Muslims is the right time for them to recite and memorize the Quran. This kind of event will undoubtedly attract visitors. Using 'SatuSuro' (first day of the month of Suro, a month in the Javanese calendar) as an event for Slametan at Gunung Kawi adapts the spread of Muslim religion to Javanese society. Suro is a month in the Saka (Javanese Hindu) calendar, which is believed to be when AjiSaka (a magic person) arrived and freed the Javanese people from giant creatures disturbing the people. The community performed Slametan to express gratitude for being saved from the giants. When the Muslim kingdom was built in Java, they wanted to change the Saka calendar to the Hijri calendar (Muslim) and avoid conflict. Between the month of Suro and Satu Muharam (the new year in the Hijri calendar) is the time for celebration and Slametan $(33,36)$.

Tourists' arrival at a particular time has a specific purpose, especially for the pilgrims. The success and feeling of spiritually blessed trigger them to revisit. They want to maintain their success or want more. As for those who felt that they had not been blessed, they will revisit to get what they 
want. Thus, the event will always make visitors come back.

Interestingly, all informants defined 'attraction' differently from previous tourism researchers. Researchers define tourism attractions as an integral concept of all aspects of tourism, such as tourism, infrastructure, and services (21,37-39), while informants understand attraction as a cultural activity or others carried out specifically to attract tourists. A further study on which definition is more effective to use the development of religious tourism is needed.

\section{CONCLUSION}

The study results put forward the views of tourists who are useful for managers of religious tourism destinations to formulate an appropriate marketing strategy. Knowing what tourists want will make establishing the right strategy easier. For the government, this study can help determine the direction of developing a tourist destination (in terms of physical development) to meet the tourists' wants as much as possible. Researchers in the field of tourism can improve the results of this initial research as a reference to develop religionbased tourism. It should not be limited to Malang only; as long as the development adopt the local culture according to the characteristics of the community and faith group, the future researcher can use the results of this study.

This study is an early-stage research and still needs to view various other perspectives to make a model that can be used for all religious tourism destinations. A more detailed and broader set of informants' characters might also affect the results of further research. Gender considerations, economic levels, locations, etc. may need to be specially assessed.

\section{REFERENCES}

[1] Wahyuni T, Susilo, Muljaningsih S. Regional Economics: How does Tourism Influence Regional Revenue of Malang Raya? J Indones Tour Dev Stud. 2018;6(2):93102.

[2] Setioko, Danang M. Analisis Strategi Pengembangan Wisata Kota Di Kota Malang. J Pariwisata Pesona. 2019;4(1):81-8.

[3] Zouni G, Digkas D. Marketing suggestions for multi-religious tourism development: The case of Thessaloniki. J Tour Herit Serv Mark. 2019;5(2):36-42.

[4] Yekinni OB, Mercy BB. Exploring the
Relationship between Religion Tourism and Economic Development of a Host Community. Int $\mathrm{J}$ Bus Manag Invent. 2017;6(9):41-51.

[5] Hardini H. Government Strategic Collaborative Partnership in Tourism Affairs A study in Malang and Batu City Governments. J Stud Pemerintah. 2018;9(3):354-77.

[6] Febrianto R, Supriyadi, Enis T, Arifien Z, Miftah K. Values of Local Wisdom in Socio-Religious Site of "Tiban" Mosque Malang (The Aspects of Society, Culture, Economy, and Technology). J Comput Theor Nanosci. 2018;24(1):420-2.

[7] Faletehan AF. 'Serenity, Sustainability dan Spirituality' dalam Industri Manajemen Wisata Religi. J Pariwisata. 2019;6(1):16-31.

[8] Soeryowidagdo RS. Pesarean Gunung Kawi: tata cara ziarah dan riwayat makam Eyang Panembahan Djoego, Eyang Raden Mas Iman Soedjono di Gunung Kawi Malang. 1st ed. Malang: Yayasan Pengelola Pesarean Gunung Kawi "Bakti Luhur"; 1989. $30 \mathrm{p}$.

[9] Sulistyorini D, Sudardi B, Warto, Wijaya M. Cultural Commodification Representation of Pesarean of Mount Kawi as Cultural Tourism in Indonesia Mass Media. J Intensive Stud Lang Lit Art, Cult. 2017;1(191):85-95.

[10] Hariyanto B. The Tradition of Kawi Mountain ( Linguistics Perspective ). THAQAFIYYAT J Bahasa, Perad dan Inf Islam. 2018;18(2):172-85.

[11] Rasoolimanesh SM, Md Noor S, Schuberth F, Jaafar M. Investigating the effects of tourist engagement on satisfaction and loyalty. Serv Ind J [Internet]. 2019;39(78):559-74. Available from: https://doi.org/10.1080/02642069.2019.1 570152

[12] Cohen SA, Prayag G, Moital M. Consumer behaviour in tourism: Concepts, influences and opportunities. Curr Issues Tour [Internet]. 2014;17(10):872-909. Available from: http://dx.doi.org/10.1080/13683500.2013 .850064

[13] Machleit KA, Mantel SP. Emotional response and shopping satisfaction. J Bus Res. 2001;54(2):97-106.

[14] Della Corte V. Customer Satisfaction in 
Tourist Destination: The Case of Tourism Offer in the City of Naples. J Invest Manag. 2015;4(1):39.

[15] Navrátil J, Pícha K, Navratilóva J. Satisfaction with visit to tourism attractions. Tourism. 2012;60(4):411-30.

[16] Mudarra-Fernández AB, Carrillo-Hidalgo I, Pulido-Fernández JI. Factors influencing tourist expenditure by tourism typologies: a systematic review. Anatolia [Internet]. 2019;30(1):18-34. Available from: https://doi.org/10.1080/13032917.2018.1 495086

[17] Chami M, Kaminyoge G, Chami M, Kaminyoge G, House C, Chami M, et al. Closed House of Wonders museum: Implications to the tourism of Zanzibar Stone Town, UNESCO World Heritage Site. J Tour Herit Serv Mark. 2019;5(1):31-6.

[18] Chenini A, Touaiti M. Building Destination Loyalty Using Tourist Satisfaction and Destination Image: A Holistic Conceptual Framework. J Tour Herit Serv Mark. 2018;4(2):37-43.

[19] Cochrane J. Spirits, nature and pilgrimage: The "other" dimension in javanese domestic tourism. J Manag Spiritual Relig. 2009;6(2):107-19.

[20] Harahap SA, Hadi D. The Infuence of Culture Tourist Attraction to the Interest of Archipelago Tourism Visit to Kotagede. J Gema Wisata. 2019;15(2):460-73.

[21] Richards G. Tourism Attraction System: Exploring Cultural Behavior. Ann ofTourism Res [Internet]. 2002;29(4):1048-64. Available from: www.elsevier.com/locate/atoures

[22] Keitumetse SO. Cultural resources as sustainability enablers: Towards a community-based cultural heritage resources management (COBACHREM) model. Sustain. 2014;6(1):70-85.

[23] García JÁ-, Erazo CP, Río-Rama M de la C Del, Álvarez FJC. Cultural heritage and tourism basis for regional development: Mapping of scientific coverage. Sustain. 2019;11(21):1-21.

[24] Olinsson SB, Fouseki K. Social entrepreneurship for sustainable heritage management - the case of open-air museums. J Cult Herit Manag Sustain Dev. 2019;9(4):486-499.

[25] Foruzan I. The Role of Religious Tourism in the Development and Growth of Urban Metropolis: (In The Case of Mashhad, Iran) Iman. Eastern Mediterranean University North Cyprus; 2014.

[26] Priyanto P. Pengembangan Potensi Desa Wisata Berbasis Budaya Tinjauan Terhadap Desa Wisata Di Jawa Tengah. J Vokasi Indones. 2016;4(1).

[27] Suarniki NN, Lukiyanto K. The role of satisfaction as moderation to the effect of relational marketing and customer value on customer loyalty. Int $\mathbf{J}$ Innov Creat Chang. 2020;13(4):108-22.

[28] Duan N, Hoagwood K. Purposeful Sampling for Qualitative Data Collection and Analysis in Mixed Method Implementation Research. Adm Policy Ment Heal Ment Heal Serv Res [Internet]. 2015;533-44. Available from: http://dx.doi.org/10.1007/s10488-0130528-y

[29] Ignatius Ekanem. A Qualitative Research Method for Small Frms. J Small Bus Enterp Dev. 2007;14(1):105-17.

[30] Lincoln YS, Guba EG. Handbook of Qualitative Research. 4nd ed. Thousand Oaks, CA: Sage.; 2000.

[31] Olanrewaju E. Social Phenomenology of Alfred Schutz and the Development of African Sociology. Br J Arts Soc Sci. 2012;4(1):12-25.

[32] Supriyadi, Febrianto R, Tristiana E, Arifien Z, Nidar MK. Values of Local Wisdom in Socio-Religious Site of "Tiban" Mosque Malang (The Aspects of Society, Culture, Economy, and Technology). Adv Sci Lett. 2018;24(1):420-2.

[33] Sholikhin KHM. Misteri Bulan Suro Perspektif Islam Jawa. 1st ed. Yogjakarta: Narasi; 2010. 300 p.

[34] Sterchele D. Memorable tourism experiences and their consequences: An interaction ritual (IR) theory approach. Ann Tour Res [Internet]. 2020;81(April 2019):102847. Available from: https://doi.org/10.1016/j.annals.2019.102 847

[35] Lukiyanto K, Widita A, Kumalasari RD. Patron-Client Relationship in Microenterprise Development as a Cultural Heritage in Modern Era. Pertanika J Soc Sci Humanit. 2018;26(S):155-62.

[36] Sulistyorini D, Sudardi B, Warto W, Wijaya 
M. Culture Tourism to Pesarean Kawi Mountain as A Culture of Cultural Products. In: Third International Conference of Arts, Language and Culture (ICALC. 2018. p. 175-80.

[37] Kušen E. A system of tourism attractions. Tourism. 2010;58(4):409-25.

[38] Lew AA. A framework of tourist attraction research. Ann Tour Res. 1987;14(4):55375.

[39] Ngwira C, Kankhuni Z. What attracts tourists to a destination? Is it attractions? African J Hosp Tour Leis. 2018;7(1):1-19. 